\title{
$\mathrm{JICA}$ 모로코 사무소의 삼각협력 (남남협력) 현황
}

1 JICA 모로코 사무소의 삼각협력 추진현황

1) 사업개시

$\square$ 모로코 정부의 요청에 따라 1998년부터 시작

\section{2) 사업형태}

$\square$ 연수생초청사업 : 불어권 블랙아프리카 연수생을 모로코에 초청해, 모로코 정부기관에서 기술연수 를 실시하며, 모로코측이 사업계획 및 추진을 담 당하고, JICA에서 항공권을 비롯한 $85 \%$ 가량의 예산을 부담함.

$\square$ 전문가파견사업 : 모로코 전문가를 블랙아프리카 지역에 파견하며 파견비용은 JICA가 부담함

\section{3) 사업규모}

$\square$ 연수생초청사업 : 연 100명 내외(과정별 20명 이내) $\square$ 전문가파견 : 1999년부터 총 14명 파견

\section{4) 사업분야}

$\square$ 수산업, 도로건설, 수자원개발

5) 모로코측 담당기관

$\square$ 총괄: 외교협력부산하 모로코국제협력단 (Moroccan International Cooperation Agency) $\square$ 수행기관 : ISTPM(수산물품질연구소), IFEER(도 로건설인력연수원/JICA 프로젝트사업 수원기관), ONEP(국립식수청) 등

2. JICA의 사업추진 절차

$\square$ 수요조사 : 모로코 사업수행기관이 사업계획서를 JICA에 제출

$\square$ 구상서체결 : 사업타당성이 인정되면 상세사업계 획을 포함하여 JICA, 모로코 외교협력부, 사업수 행기관 간 약정을 체결함(첨부 구상서모델 참조). 삼각협력에 관한 모로코- 일본 양자간 협정은 별 도로 없으며, 프로젝트 형식으로 단위 사업별 구 
상서가 체결됨.

$\square$ 사업수행 : 모로코 수행기관이 담당

$\square$ 사업평가 : 총 3회에 걸쳐 JICA에서 실시(매년 사 업종료시, 전체 사업종료시, 전체사업종료후 3년 경과시)

\section{3. 기타}

$\square$ JICA 모로코 사무소 Obata 부소장은 JICA가 삼 각협력보다는 남남협력이라는 표현을 주로 사용 하고 있음을 밝히고, 동 사업의 효과가 일본내 연 수생초청 및 전문가파견사업에 비해 두드러진다 고 평가하기는 어려우나 모로코와 같이 남남협력 에 관심을 갖는 개발도상국에 기회를 제공한다는 측면에서 큰 의의가 있다고 밝힘.

$\square$ JICA 는 현재 아프리카 지역에서 모로코 외에 이 집트, 튀니지에서도 삼각협력사업을 추진하고 있 으며, 동 사업추진시 수원국인 블랙아프리카지역 JICA사무소와의 공조를 통해 사업타당성조사 및 평가를 실시하고 있음.

4. 주모로코 대사관 검토의견

$\square$ 모로코는 아프리카 역내에서 상대적으로 안정된 교육관련 인프라를 구축하고 있는 것으로 판단되 며, 한국 및 모로코와 불어권 아프리카국가 대상 삼각협력사업 추진시, 의사소통 면에서 사업효과 를 제고할 수 있을 것으로 기대됨.

$\square$ 그러나 남남협력을 제반 정책적 고려 하에 우선사 업으로 추진 중인 일본과는 달리, 우리나라는 무 상원조 예산의 제약이 큰 바, 남남협력의 기대효
과뿐 아니라 우리나라의 원조효과를 거양할 수 있 는 사업을 발굴해야 할 것으로 사료됨.

$\square$ 따라서 사업전반을 모로코에 일임하는 일본의 모 델보다는, KOICA 프로젝트 수원기관 및 파견전 문가를 활용하여 예산뿐 아니라 기술적 측면에서 삼국이 협력하는 방안을 모색하는 것이 보다 적절 한 협력방안인 것으로 사료됨.

- 한 예로, KOICA는 2004 05년에 걸쳐 50만 불 규모의 자동차정비직업훈련 교사연수원 개 선사업을 수행하였으며, 모로코 직업훈련청은 동 시설에서 자체적으로 블랙아프리카대상 연 수사업(무상원조)을 실시중인 바, 동 사업을 삼 각협력사업으로 확대하여 시범 추진할 수 있을 것으로 보임.

- 동 수원기관에는 우리나라 전문가를 장기 파견 하여 연수과정 전반에 참여토록 함으로써 교육 효과를 제고함.

[자료 : 주모로코 대사관] 